\title{
Mezigenerační proměny sociálních identit obyvatel Hlučínska
}

\author{
Generation Identity Changes in the Hlučín Region \\ Marcel Mečiar
}

\begin{abstract}
The historical micro-region of Hlučín at the northeastern border of the Czech Republic became an object for political contention between Czechoslovakia and Germany in the Inter-War Period. The process strongly influenced the inter-war generation of Hlučín inhabitants, with a partial impact imposed on the next two generations. This article is focused on the changes in social identity formation in four generations of Hlučín autochthons. The author's approach is based on the concept of historical generation. Life experiences, and their embeddedness in a historical memory, form a crucial element of the study. The data sources consist of biographical-narrative interviews with informants from three generations, written autobiographies, and reflections found in the works of regional authors (providing data coverage for the first generation being described). This investigation reveals a change in intergenerational relations between particular members of several families from the Hlučín Region, because this social space enables an observation of intergenerational communication, negotiation and reflection of experiences.
\end{abstract}

KEY WORDS Generation, Hlučín Region, intergenerational change, social identity

\section{Generace Hlučíňanů}

Přístup, jenž byl vypracován pro analýzu generací na Hlučínsku ve 20. století, kombinuje prvky historického a genealogického konceptu generace (Veith 2006a, Veith 2006b, Mišíková a Kövérová 1992). V duchu této práce a ve šlépějích Johna A. Vincenta (2005) a Michaela Corstena (1999) vycházíme z pozice, že generace je sociální konstrukt kontingentní povahy, jenž může být re/konstruován a reprezentován skrze reflexi svých členů či skrze interpretaci této reflexe těchto reprezentací nezávislým pozorovatelem. Na kontingentní povahu historické generace mají vliv významné události, které působí na kohortu osob v dané fázi životního cyklu. Vliv intersubjektivní zkušenosti ovlivňuje identifikační potenciál generační identity (Mannheim 1952). Proto některé generace vystupují vně pouhého genealogického pojetí a formují historickou generaci a některé zůstávají z perspektivy sociální generace pouze mechanicky vymezitelnou kohortou (Edmund a Turner 2005).

Z pohledu konceptu, který generace obvykle definuje jako kohorty osob narozených v rozmezí 20 až 30 let, došlo v níže představeném výzkumu k poněkud odlišnému rozdělení. Chceme-li se držet postupu rozpoznání tří generací v rámci rodiny, nelze generace

Sociální studia. Fakulta sociálních studií Masarykovy univerzity, 1-2/2007. S. 97-114. ISSN 1214-813X. 
identifikovat striktně po dvaceti či třiceti letech (Svátek 1998). Jasnější kostru poskytne příbuzenská posloupnost vyjádřitelná jednoduše následovně: prarodiče - rodiče - děti (starší střední - mladší generace), nahlížená zároveň na pozadí uvedeného konceptu „společného generačního ducha“, podle kterého vrstevníci jedné generace sdílejí některé společné sociální atributy (Howe a Strauss 1992). Věk sice úzce souvisí s historickou determinací, přesto existuje distinkce mezi pojetím věkové (rodinné) a historické generace (Lüscher 1993). Takto získané analytické vymezení generací obyvatel Hlučínska s ohledem na sdílený čas, prostor a děj(inné události) prezentuje Tabulka 1.

Tabulka 1: Biografické uchopení hlučínských generací

\begin{tabular}{|c|c|c|}
\hline $\begin{array}{l}\text { Historické generace } \\
\text { (pracovní názvy) }\end{array}$ & Perspektiva věkové generace & $\begin{array}{l}\text { Časová koordináta/ } \\
\text { biografická konfigurace }\end{array}$ \\
\hline $\begin{array}{l}\text { „Pruská generace } \\
\text { - generace 1. světové } \\
\text { války“ }\end{array}$ & nejstarší (již nežijící generace) & $\begin{array}{l}\text { narození povětšinou před 1. světovou } \\
\text { válkou }\end{array}$ \\
\hline „Mezi/válečná generace“ & $\begin{array}{l}\text { starší (cca prarodiče dnešních } \\
\text { 20-30tiletých) }\end{array}$ & $\begin{array}{l}\text { narození před 2. svět. válkou (v době } \\
\text { války alespoň školou povinní) }\end{array}$ \\
\hline „Socialistická generace“ & $\begin{array}{l}\text { střední (cca rodiče dnešních } \\
\text { 20-40tiletých) }\end{array}$ & $\begin{array}{l}\text { narození po 2. svět. válce cca do konce } \\
50 \text {. let }\end{array}$ \\
\hline „Generace roku 89““ & mladší (lidé zhruba mezi 20-40 lety) & $\begin{array}{l}\text { narození v období od } 60 \text {. let do poloviny } \\
80 \text {. let }\end{array}$ \\
\hline
\end{tabular}

Pamatujíce na slova Charlese W. Millse ([1959] 2002), jenž považoval za důležité pochopit smysl biografie člověka (jeho jednání) na pozadí historických daností (struktura, temporalita), lze dojít k předpokladu, že odlišné životní zážitky mohou být klíčem k poznání rozličných identifikací. Jinak bude konstruovat svoji subjektivní realitu „prarodič“ narozený před válkou či během války, jinak „,rodič“ s živým zážitkem postavení hlučínského obyvatelstva „Za socialismu“ a zase trochu odlišně „dítě“ čili př́íslušník nejmladší generace (v současnosti ovšem již dospělý člověk).

Názvy pro čtyři historické generace jsou zformulovány na základě následujících poznatků a názorů. „Pruská generace či generace 1. světové války“ je první generací, která vstupuje do 20. století v životní fázi dětství či mládí. Stává se „tichou“ generací, která se setká se dvěma silně (de)formativními zážitky - s oběma světovými válkami. Generace označená jako „mezi/válečná“ se socializuje v meziválečném období či během 2. světové války. První jejími př́slušníky subjektivizovanou realitou je doba konce první republiky a sílící vliv národně-socialistického Německa. Pro členy této generace je typickým znakem zlom ve zkušenosti, změna jimi poznaného sociálního řádu a střet $\mathrm{s}$ formami symbolického vymíst'ování po opětovném připojení $\mathrm{k}$ Československu. Lidé, kteří mohou být pojati jako součást „socialistické generace“, citlivě vnímali reflexe svých rodičů a jimi nově vytvářené definice dřívějších dějinných událostí pojímali jako konfliktní rámce (např́iklad Německo jako dobro, které „,nám dalo práci“ vs. Německo a Němci jako původci všeho zla). Členové této generace se stávají součástí socialistické společnosti přesto, že si zachovávají své distinkce v podobě odlišné zkušenosti rodičů a hodnot a norem typických pro mikroregion Hlučínska. Jejich specifičnost spočívá v prožití předproduktivní a větší části produktivní fáze života za „želez- 
nou oponou“. Právě pro „generaci roku 89“ je významným odlišujícím znakem zážitek další změny řádu $\mathrm{v}$ začátku produktivní fáze života a možnost a schopnost nové reflexe dřívějších událostí, což lze chápat jako jednu z forem reprezentací sociálních identit v proměnách.

\section{Nejstarší, „pruská“ generace}

Členové nejstarší hlučínské generace již nejsou mezi živými, přesto lze zrovna u této generace nalézt signifikantní reprezentace identit díky dochovaným textuálním datům. Se členy této generace nebylo již možné provést rozhovory a zvukové záznamy z dřívější doby se nepodařilo nalézt a zajistit. Zůstávají tedy texty auto/biografické povahy (korespondence a memoáry) a beletrie psaná členy této generace.

Pruská generace či generace 1 . světové války se primárně socializuje v období posledních let vilémovského režimu v Německu, před 1. světovou válkou a během ní. Formativní vliv na její generační identitu mají zejména výsledky Versailleské konference, která přiřkla území jižního Ratibořska (Hlučínska) Československu. Po připojení v roce 1920 vstupem českých vojsk a zavedením správy, která bývá ve vyprávění běžných aktérů interpretována jako „okupačni““ („Jak nás zabrali Češi, byli jsme Češi“) se Hlučíňané ocitli v nových socioekonomických podmínkách a v jakémsi sociální vakuu. Starší segment pruské generace $\mathrm{v}$ tomto období budování mladičké a nejisté republiky zrovna vstupoval do životní fáze výchovy dětí.

To jsme patřili ještě k Německu a ve všech dědinách na Hlučínsku byly jen německé školy. Naše Františka chodila tehdy už druhý rok do školy a jednou v zimě přišla velmi uplakaná. Celá uslzená vypravovala, že se s nimi učitelé ve škole loučili. Prý Hultschinerländchen připadne k Československu. A sem k nám ted' přijdou čeští učitelé. Ale ony, děti, aby nezapomínali na německou říši. Potom jim opakovali třikrát „Auf Wiedersehen!“ [...] Potom se u nás v dědině ledacos změnilo, ale rodiče byli rok co rok zamlklejší, ustaranější. Jen Vilém, který toho roku nastoupil do české školy, přicházel domů rozesmátý, a kupodivu, Františka také. Čeští učitelé, kteří je ted' učili, mluvili s nimi „pomoravsky“ a nebyli vůbec zlí. [...] Rodiče však zůstávali stále ustaraní. Co bude dál? Od Ratiboře dojížděli k nám podivní lidé. Po večerech navštěvovali jednotlivá stavení. A neposlouchejte české úruady. „Die Čechaj nebude dlouho vaší vlastí.“

(Hořká 1975: 191, narativní ohnisko: kolem roku 1920)²

1 I navzdory nebezpečí mylné interpretace přes filtry literární licence a subjektivizace stojí za to pokusit se pracovat i s čistě literárními texty. Právě zabývání se subjektivitou je sociologickým úkolem (Konopásek 1998: 76).

2 Ludmila Hořká (vlastním jménem Marie Šindelářová, 1892-1966) se věnovala národopisné práci i vlastní tvorbě, ve které, vzhledem $\mathrm{k}$ tomu, že její př́íběhy pocházely z rodného kraje a byly o rodném kraji (Hlučínsku), často používala autobiografických zkušeností a vzpomínek. Hranice mezi fikcí a realitou je přirozeně nejistá a nejasná, přesto nelze zpochybnit autorčinu úlohu jako mluvčí své generace. Je-li dílo odrazem autorova myšlení, je do značné míry reprezentací jeho identity (vědomě i nevědomky). Hořká je schopna svým dílem vysvětlit a prezentovat pestrou mozaiku hlučínského diskurzu (z pozice samotných Hlučínanů), sic si musíme být vědomi jisté potenciální „zastřenosti“ vlivem poválečné a socialistické doby. Tak je Hořká svými názory i činy (založení lidového souboru, osvětová činnost v meziválečném období) reprezentantkou pročeského diskurzu na Hlučínsku. 
Přestože uvedená ukázka na prvém místě vypovídá o adaptaci dětí na nové podmínky, povšimněme si více situace a role rodičů. Ve změně sociálního řádu životního světa rodičů spočívá neuralgický bod traumatu, díky kterému bylo utuženo generační vědomí pruské generace. ${ }^{3}$ Vedle otázky př́slušnosti, v rámci které se ocitají mezi mlýnskými kameny zájmu dvou států (poražené velmoci a mladičké republiky), jsou rodiče nuceni řešit praktické problémy každodennosti - zaměstnání, obživa, vzdělání a výchova dětí. Přesně z této doby a životní fáze pochází reflexe Ludmily Hořké, jejíž myšlenky z povídky Hanys Bejamin představuje výše uvedená citace. Je v ní patrné, že hlavní bojiště „Kulturkampfu“4 se rozvinulo v prostředí školy. Vzdělání do značné míry definovalo možné rámce etnické identifikace. Díky pečlivé práci historiků můžeme subjektivní pohled doplnit i studiem a interpretací pramenů. Hořká popisuje více méně ideální typ, jenž je formován pročeským diskurzem. Děti jdou do české školy a až na drobná jazyková nedorozumění se lehce integrují. Existoval ovšem i jiný pohled a př́stup rodičů, kteří hodlali i nadále posílat své děti do německých škol, aby si zachovali znalost „praktického“ (z hlediska zaměstnanosti) jazyka, pokud se př́mo neidentifikovali jako Němci.

Vedle „mlčící většiny“ lze po roce 1920 identifikovat skupinu jasněji vyhraněných obyvatel Hlučínska, kteří optovali pro Německo, kam se také museli odstěhovat, doufajíce, že se poměry v poválečných letech brzy změní. Jedním z nich byl i budoucí věhlasný slezský spisovatel August Scholtis (1901-1969). Jsa rodákem z Bolatic, lze jeho původ označit jako hlučínský. Tím však jasnost kolem jeho identifikací s kolektivitami končí. V různých kontextech hovoří a píše o rozličných kategoriích př́islušnosti. Vyjdeme-li z jeho biografie, zjistíme, že pocházel z bilingvního prostředí, což mělo na jedné straně vliv na jistou dualitu či vícepólovost a na straně druhé na nejednoznačnost, nevyhraněnost (indiferenci), co se týče jeho národní a regionální identity. „Byl jí zatížen stejně jako jeho vrstevníci, kteří žili jako on na národnostně rozpolceném Hlučínsku, “ dodává hlučínský historik Plaček (2000: 142). Scholtisova sebe-identita je plná rozporů. Rád zdůrazňoval, že jeho matka byla moravskou selskou dcerou, přestože její bratři byli německými důstojníky (v době do roku 1920, kdy Hlučínsko bylo součástí Německa) a jeden byl dokonce plukovníkem u letectva (Plaček 2000). ${ }^{5}$ August Scholtis se setkal s němčinou, jako mnozí jeho vrstevníci, až po nástupu do školy, v jeho orientační rodině se hovořilo moravsky. Učitel Karel Schodrok, který

3 Tvrzení o vzniku a upevnění generační identity lze podepřít konceptem kulturního traumatu (například Eyerman 2004), jenž popisuje formování kolektivních identit v čase krize a v důsledku traumatických zkušeností „uložených“v kolektivní paměti sdílejících.

$4 \quad$ Kulturkampf čili kulturní boj byl zápasem o identitu obyvatelstva na etnicky smíšených či indiferentních územích. Na Hlučínsku se projevoval zakládáním českých a rušením německých škol, zákonnými obstrukcemi, zakládáním českých spolků na straně jedné a snahou zachovat německé školství na straně druhé, v prŕípadě nepřízně i soukromou výukou (známý Privatunterricht). Svůj původní význam nachází v politickém programu říšského kancléře Otto von Bismarcka, jenž by zacílen proti vlivu římskokatolické církve, zejména na území protestantského Pruska. Hlavní fáze zavádění sankcí proti katolicismu proběhla mezi lety 1871-1878 a ze sociologického pohledu měla nejen diskriminační, nýbrž i modernizační charakter (například institucionalizace občanských sňatků).

5 Což dokládá, že institucionální brány byly pro Hlučíňany jako říšské občany (a menšinu) otevřené, nehledě na jejich odlišnou etnicitu (Moravec/Slovan) a religiozitu (katolík) oproti majoritě. 
v letech 1910-1914 vyučoval v bolatické škole, svým učitelským umem zdárně vedl své žáky $\mathrm{k}$ německému patriotismu. $\mathrm{V}$ německém jazyce se Scholtis na úroveň rodilého mluvčího dále zdokonalil v administrativních službách u knížete Lichnovského v Chuchelné. ${ }^{6}$ Perfektní znalost němčiny mu později umožnila kariéru německy píšícího spisovatele. V roce 1920 optoval pro Německo, kam se o dva roky později též odstěhoval a kde na konci dvacátých let začal dráhu spisovatele.

V Scholtisově tvorbě a dochované bohaté korespondenci nacházíme četné reprezentace indiference v hájemství etnicity. Rozdělme si nyní, čistě analyticky, Scholtisovy formulace podle toho, zda jsou součástí pročeského nebo proněmeckého diskurzu. V rámci pročeského diskurzu lze jako signifikantní uvést větu z dopisu adresovaného Petru Bezručovi (z roku 1946), ve kterém pesimisticky vyhodnocoval své spisovatelské šance na území Slezska po vysídlení drtivé většiny německy mluvícího obyvatelstva. Přesto ale „definitivní“ náležitost rodného kraje k Československu kvitoval s uspokojením. „Z toho, že se má užší vlast stala českou, mám radost a závidím budoucím generacím, že budou konečně vědět, ke které národnosti patřri“ (Scholz 1991). Nepovažoval se za Slezana, nýbrž za „Musspreusse“" z moravskoslezského pomezí. Byl tedy „Prusem z donucení“, ale navzdory prvku donucení v důsledku historických konsekvencí se s pruskou výchovou a mentalitou sžil natolik, že se považoval za Němce, byt' zároveň za Moravce (obyvatele Hlučínska). Z těchto rozporů nyní můžeme rekonstruovat Scholtisovu „mozaiku sociálních identit“ jako Hlučíňana v rovině regionální identity a Němce z pohledu národní občanské identity, který si je však vědom svého slovanského původu, a proto vítá př́slušnost Hlučínska k Československu. Někdo by si řekl: „To je pěkný guláš.“ Ale toto je osud lidí z pohraničních oblastí států střední Evropy 20. století. Implicite ze Scholtisova odkazu vychází výsledek, že bez konfliktního vlivu soupeřících nacionalismů by bylo lidem (nejen) ve Slezsku lépe.

Zážitek (kulturního) traumatu a vědomí rozpolcenosti identifikačních vazeb můžeme považovat za konstitutivní prvky generačního vědomí Scholtisovy generace. Tyto prvky byly zachovány a později dokonce posíleny u následující generace a daly základ specifičnosti identity obyvatel Hlučínska.

\section{Nástup meziválečné generace}

Přestože se situace na Hlučínsku do konce dvacátých let 20. století v otázce školství do značné míry konsoliduje, hospodářská krize počátku třicátých let počne účinně povolovat vzniknuvší identifikační vazby ekonomicky aktivních Hlučínanů k ČSR. Vypjatou situaci nezaměstnanosti a bídy ukazuje povídka L. Hořké (1975) Bejatka. V níže uvedené ukázce dochází k interakci mezi českým učitelem placeným státem a hlučínskou ženou s několika hladovými dětmi a nezaměstnaným manželem.

Slyšíte naříkavé hlasy: „Češi Hlučínsko chtěli, ale o robotu se mu něpostaraju.“ Vidíte vyhublé děti bledých horečnatých očí z hladu a to je nejtruchlivějš́í. Včera zastavil na dědině učitel jednu robku a proč prý nechodí synek do školy. „Bo něma co obut'.“ „To není omluva,“ praví učitel. A tu ta robka

6 Jedná se rovněž o hlučínskou obec. 
vezme učitele za ruku a ř́ká mu: „Pane učitel, sem rozumna robka a vim, že sem Moravka a ni Prajzula. Ale to něni ene tak, naši mili Hučiňaci, včil smy vas od Prajzuv osvobodili, padnitě před nama za to na kolena! Ni, pane učitel! Ti pani, co na chtěli, měli prvšo dobře uvažit, eli nam možu dat' ty zarobky, co smy měli pod Prajzem, jak už nam němohli dat' vjec. Ja sem včeraj prodala peřinu a kupila za ňu pro děti chleba!““

(Hořká 1975: 154)

Hořké (1975) se daří prezentovat významný prvek hlučínského diskurzu o příslušnosti k ČSR dané doby. Z intersubjektivního pohledu obyvatel je nejistota („Co s námi bude?“) vystř́iána jistotou („Bude s námi zle.“). Pro patriota je asi nepochopitelné redukovat význam př́slušnosti ke svému národu na otázku ne/dostatku. Narativa nastupující generace však ukázala, že práce ve spojitosti s obživou jsou často centrálními kategoriemi biografií konverzačních partnerů. Lze to vysvětlit tak, že otázka důstojného přežití byla velmi palčivá. Z pohledu současného konceptu multikulturalismu vyšel obyvatelům Hlučínska pro nacionalisty nelibý výsledek, že jako cizorodé menšině v Německu jim bylo lépe než v pozici nedůvěryhodné menšiny ve staronové ,vlasti“. V kolektivní paměti sdílené sociální identity Hlučíňanů zůstaly vzpomínky na určité formy diskriminace při hledání zaměstnání. I z toho se posiloval pocit „oběti“ mocností a nemohoucnosti první republiky.

Někdy i čeští nacionalisté nepřímo podporovali touhu po připojení obyvatel Hlučínska k Německu. Vyprávěl mi kolega, původem z Kozmic na Hlučínsku, že za první republiky byli obyvatelé tohoto území i diskriminováni. Protože se mi to nezdálo, dal jsem si diskriminaci vysvětlit. Vyprávěl, jak jeho otec hledal v Ostravě práci. Mimo jiné navštívil i Vítkovické železárny. Nějaký úředník se ho ptal, co si přeje. Vyslovil prosbu o zaměstnání. „A odkud jste? Z Kozmic, aha z Hlučínska, tak to si místo hledejte někde jinde, vás nebereme.“ Čeho chtěl onen „vlastenec“ takovou odpovědí dosáhnout? Stejně volné místo neměl a docílil jen toho, že se ruce sevřely v pěsti (zatím jen v kapsách) a postižený si také jen zatím řekl „es kommt der Tag“ (přijde den).

(Martiník 1997: 19)

Vysoká nezaměstnanost a nízká úroveň mezd ukázala slabost první republiky i vnuceného vztahu ${ }^{7}$ Hlučíňanů k ní. Kulturní identifikace skrze moravský dialekt češtiny a zavedení českého školství se sice rozvíjely, ale se stejnou úspěšností byl zachováván bilingvismus, německé školy v Opavě a soukromé vyučování na Hlučínsku, sponzorované krajanskými spolky z nedalekého německého Ratibořska. Ekonomická krize znamenala omezení v získávání zdrojů obživy v ČSR a působila jako faktor pudivě působící na pracovní migraci do postupně se vzmáhajícího Německa, které začínalo zbrojit a rozvíjet sociální politiku „plné zaměstnanosti““ (Siegel 1985).

[...] prace bylo pro takych co, enem pro dvorskych, co ve dvoře bydleli, viče? A tak jsem si vyrobila pas, a tu cela dědina a to už Male Hoštice tak ni, ale Velke Hoštice, Kravaře a cely to Hlučinsko, všeci chodili do Německa do roboty na polo. [...] No ja, ja jsem měla ani čtrnact rokuv a už jsem chodila na panske, [1] bo mi neměli peniz.

(A. T., žena, 82 let, narativní ohnisko: rok 1937)

$7 \quad$ Vztah byl vnucený potud, pokud bereme v potaz interpretace historiků, že obyvatelé Hlučínska přijali prripojení k ČSR s nevolí a s pasivním odporem, nebot' akce slezských elit v rovině diplomatické byly neúspěšné. 
Ekonomicky aktivní byli i mladiství a největší složku migrantů za prací do Německa tvořili samozřejmě živitelé a živitelky rodin. Fakt, že pracovní migranti z Hlučínska byli přednostně přijímáni (jako důsledek propagandy i dobrého renomé pracujících $\mathrm{z}$ tohoto regionu), jen posiloval odstředivé tendence od pozitivního vztahu $\mathrm{k}$ ČSR směrem $\mathrm{k}$ důvěře vi̊či sílícímu Německu. Právě zlom ve viŕ̌e i oné části obyvatel Hlučínska původně nakloněných myšlence Československa jako „návratu do vlasti“ a zklamání ostatních se formuje jako významná generační zkušenost tzv. meziválečné generace.

Dalším vlivným činitelem působícím na meziválečnou generaci v regionu byla sílící německá národně socialistická propaganda. Jako současníci organizované modernity byli Hlučiňané podrobováni vlivu masových médií. Vedle novin mocně zapůsobilo nové médium rádia čili rozhlasu. Jako první se s ním setkali hlučínští pracovníci v Německu, kde bylo zavedeno povinné poslouchání rozhlasu při projevech říšského kancléře Adolfa Hitlera. Další formou šíření ideologicky zpracovaných informací byl pojízdný biograf. V době po připojení v roce 1938 bylo poslouchání rozhlasu povinné (zavíraly se kvůli tomu i obchody) a návštěva biografu se též „očekávala“.

Film se promítal $\mathrm{v}[\ldots]$ a muselo to být již po vypovězení války Polsku, nebot' si vzpomínám, jak Poláci nahnali německé občany, ženy, starce a děti do jednoho sklepa. Do okna sklepa strčil polský voják hlaveň kulometu a při střelbě ji jeden starý Němec zvedal nahoru, takže se nepodařilo nikoho zastřelit. Stařec měl samozřejmě popálené ruce, které mu nějaká žena ovázala hadry. Když Poláci zjistili, že se jim nepodařilo německé občany zastřelit, začali shánět granáty, které chtěli použít. Vtom najednou bylo slyšet hukot letadel. Samožrejmě německých. Všem se ulevilo. [...] Když se ale perutě letadel ukázala a začala bombardovat, bylo vidět, jak Poláci panicky utíkají, změnil se sál $\mathrm{s}$ trochou nadsázky ve fotbalové hřiště, kde domácí zrovna střelili gól.

(Martiník 1997: 20)

Jak je patrné z citace z autobiografie L. Martiníka, svět hyperreality (Baudrillard 1988) byl konstruován již tehdy za pomoci pohyblivého obrazu a zvuku s železnou pravidelností tzv. týdeníků. Agresor (Německo) umně vykresluje napadené (Polsko) jako krvelačné zrůdy, které páchají teror na německé menšině. Agresor posléze získává obraz osvoboditele. Jak významný dopad mohly mít propagandistické filmy na tehdejší dospělé proněmecky orientované obyvatelstvo, o dopadu na mládež ani nemluvě? Ztotožnění se s „dobrem“ není těžkým úkolem, což neznamená, že neexistovali lidé, kteří by tuto mediální masáž neprohlédli. Báli se však ostře a otevřeně vystoupit, nebot' by byli umlčeni a $\mathrm{v}$ rámci komunity společensky znemožněni.

Ne vše, co bylo německé, vyvěralo ze zřídla národního socialismu. Nesmíme zapomenout na zkušenosti a vzpomínky nejstarší generace na jiné, vilémovské Německo. Abychom pochopili obsah a význam názvu pruské generace a zároveň její přrirozenost, cituji z přepisu rozhovoru s paní, které bylo v roce 1938 sedmnáct let a pamatuje si na reakce vrstevníků svého otce (právě „pruské generace“). Lidé Hlučínska patřící k pruské generaci, kteří si skrze katolicismus zachovávali kulturně-náboženské vazby na Moravu a sami se ve vzpomínce na to označovali jako Moravci, vnímali opětovné přičlenění $\mathrm{k}$ Německu jako návrat ke starému (kýženému) řádu. Politická občanská identita zůstala $\mathrm{v}$ předvečer války věrná Německu. 
[...] ten taky stary, ten měl vyznamenání z války, ten ten plakal úplně, že přišli, ti staří ludé všeci vítali tych Němcuv a potem byl ten švigerfotr Richard, že šli s fakulama. A to měli take fakule a to jsme šli do teho bunkru, tam na vrch. Tam při tem bunkru, byl jakysi proslov, ale ja už to něpamatam. To jsem byla, to bylo v osmatřicátém roku, to jsem měla 17 rokuv. No ale tež jsem šla na ten, to všeci. To vím, že tam byla taka řeč, měli, to mě moc nezajimalo.

(E. R., žena, 85 let, narativní ohnisko: rok 1938)

Emotivní reakce pamětníků 1. světové války byla zčásti vzbuzena oživením válečných zážitků a traumat (vstup ozbrojených vojáků do obce). Významným prvkem však bylo to, že tito lidé vnímali přičlenění Hlučínska (či jejich obce) k Německu jako návrat „zpět do vlasti“, tak, jak slibovala nacistická propaganda. Nemuseli mu však přisuzovat tento nový národně socialistický význam. „Návrat do vlasti““ nemusel znamenat ztotožnění se s nacistickou ideologií, byt' i těchto projevů nebylo Hlučínsko této doby prosté. Spíše se jednalo o navrácení do starého řádu, kde vše fungovalo, jako kontrastu vưči špatné funkčnosti sociálních a ekonomických institucí první republiky. Z toho vyplývají dodnes tradované výroky „Hitler nám dal práci“, „Hitler zrobil pořadek“. Z tehdejšśho subjektivního pohledu obyčejných lidí z pohraniční oblasti nebyl ještě Hitler odhalen jako „fanatik“ či „válečný štváćc. Uvažovalo-li se v rovině přináležitost ke státu, tak prŕíslušnost k Německu znamenala konsolidaci sociálních podmínek.

L. Hořká (1975) se v rámci své povídkové tvorby pokouší vyrovnat s nacistickým traumatem. Přestože lze podotknout, že myšlenky obsažené $v$ jejím díle jsou determinovány dobou (období socialismu šedesátých let minulého století) a její sociální pozicí (spisovatelka uznávaná režimem), nezdá se, že by z jejích knih prvoplánově čpěla komunistická ideologie a ani „mezi řádky“ jí moc nenajdeme. Autorka si spíše implicite, podobně jako německá autorka Anna Seghersová vysloveně, klade otázky: „Kdo se stává nacistou?“ a „Jaký typ osobnosti je náchylný k přijetí nacistických hodnot?" Theodor Adorno (1950) podal odpověd' v podobě konceptu autoritářské osobnosti. Jak se tedy formuje autoritářská osobnost charakterizovaná vlastnostmi jako slepá víra v autority, netolerance, rigidita, černobílé vidění světa a sklon k násilí? Formování autoritářské osobnosti se daří ukázat Hořké (podobně jako později Seghersové [1977]) na př́běhu dvou bratrů, jejichž životy se vydají rozličnými směry. Oba chlapci zapadali do Adornova schématu př́liš rigidní či chladné výchovy. Otec, dlouhodobě nezaměstnaný (ale s tímto stavem spokojený) muž, se nestará o chlapce dostatečně, když matka odjíždí pracovat do Německa na celou sezónu (od jara do konce srpna). Matce se daří vytvořit vztah pouze s mladším synem. Starší syn se uzavírá do sebe, dospívá. Žena s tichým děsem pozoruje, jak si starší syn libuje v prohlížení obrázkových časopisů s uniformovanými SS-many. Později se její obavy naplní. Jako říšský občan nastupuje urostlý a nepřístupný starší syn k Waffen-SS a později se matka dozvídá, že jeho kariéra „vrcholí“ v roli dozorce nejmenovaného koncentračního tábora. Mladší syn později též narukuje jako řadový voják a je zastřelen na západní frontě za dezerci - snaží se přeběhnout do zajetí. Matčin svět se hroutí, ani jednoho syna již nespatří. Starší syn se vzhledem ke své „kariéře“ v rodné obci po válce už nikdy neobjeví. Jedna věc tu však nesedí. Děti nebyly vedeny k přemrštěnému patriotismu v rodině. Na osudu zejména staršího chlapce také zapracovala ,prodloužená ruka státu“ (řečeno s Pierrem Bourdieu [1998]) - instituce školy. Rámec výchovy ovlivňují vedle rodiny škola, vrstevnické skupiny a sociální pozice a ekonomické faktory. Všechny spouštěče, jak víme z osudů obyvatel tehdejšího Hlučínska, byly nastaveny do 
záporných hodnot. Edelstein (2005) poukazuje zejména na funkci školy v procesu formování autoritářské osobnosti (se sklonem k extrémní pravici). V povídce A. Seghersové ruku v ruce s chudobou a marginalizací ovlivňují postoje žáků učitelé. Hlavní hrdina Fritz je deprimován progresivním a liberálním učitelem, který jej přetěžuje, a on nestačí dostát jeho nárokủm. Tím se uzavírá jedna z kladnějších cest. Raději poslouchá slova jiného učitele, jenž je aktivním nacistou a který instrumentálně využívá Fritzových nedostatků a nasměruje jej ke kultu násilí. Podobně jako u Hořké se z něj stává namísto průměrného muže masový vrah posvěcený nacistickou mocí.

Př́běhy, které píše život, mnohdy překonávají i literární fantazii. V autobiografické reflexi L. Martiníka se setkávají pracovník Fondu obnovy národního majetku z Prahy a tajemník národního výboru jedné z hlučínských obcí. Po pár skleničkách alkoholu rozprava vesele proudí, až se tajemník zeptá pražského inženýra, proč má - jako muž lehce přes třicet let - pouze jeden zub. Inženýr vysvětluje, že téměř o všechny zuby přišel jako parašutista operující v partyzánské síti s rozsahem od Kroměřiže až po Ostravu poté, co byl v roce 1944 mučen Gestapem. Stalo se tak po vyzrazení jednoho agenta pracujícího pro a za peníze, který „hrál“ na obě strany. Inženýr v polovědomí musel vyzradit potřebné informace, nebot' výslechy nakonec přežil a skončil $v$ koncentračním táboře. Po př́ijezdu do tábora naposledy viděl svoji ženu a dítě, o kterých se nacisté patrně dozvěděli u výslechů. Celou dobu rozpravy si inženýr a tajemník notovali a znali všechny gestapáky a dozorce.

Nakonec pan inženýr ř́ká: „Ted’ mi povězte, odkud všechny tyto informace máte?“ Pan tajemník řekl: „Já jsem byl náčelníkem německé četnické stanice, takže jsem dost často s těmi lidmi př̌ǐel do styku.“ [...] Při loučení pražský host podal zástupci národní výboru ruku a ř́ká: „Přeji Vám hodně štěstí, bylo to zajímavé setkání, u nás v Praze byste však dopadl poněkud hưře."

(Martiník 1997)

Členové nejstarší a starší generace prožívali, jedni již jako zralé a dospělé osoby, druzí jako děti a mladí, hrůzy 2. světové války. Opět se potvrzují Giddensova slova (1991, in Mars 1999: 21), že „volby nejsou v hledání sebe-identity činěny dekontextualizovaným jedincem, nýbrž v kontextu sociálních sítí a zdrojü“. Tyto volby jsou prováděny v rámci zahrnujícím stát, způsoby ekonomické produkce a vztahy v sociální skupině samotné. Sebe-identita byla ovlivněna ideologií státu. Z rozhodnutí státu (a mocností - Mnichovská dohoda) se Hlučínsko stalo integrální součástí německé Třetí říše. Zákonnou úpravou se všichni obyvatelé (a jejich manželky a děti) narození na Hlučínsku před rokem 1910 a žijící zde v roce 1938 stali ř́̌šskými občany. Tak se na hlučínské muže začala vztahovat i německá branná povinnost. Mladí mužové, kteří absolvovali povinnou vojenskou základní službu v československé armádě, stanuli na druhé straně bojiště. Jedni z přesvědčení, druzí z donucení. Do administrativní služby armádě v blízkosti východní fronty se dostaly i hlučínské ženy. Ti, kteří přežili, se postupně vraceli do svých rodných obcí ze zajateckých táborů mnohdy až dva roky po skončení války, než se podařilo vyřešit nezbytné právní otázky v oblasti jejich občanství.

Válečné zážitky a pozice na straně Německa způsobují, že Hlučíňané z větší části nesdílejí postoje a zkušenosti společné jiným obyvatelům po válce obnoveného Československa. Protifašistický odboj se omezuje na několik osob hlučínského původu a na spolupráci na několika akcích na konci války (Pavlíček 2003). Hlučíňané čelí germanizaci, kterou nepoznala ani 
generace žijící od období po vzniku Bismarckova Německa (1870) až do doby po připojení k Československu. V tomto období zachovával německý stát prostor pro „bytí Němcem“ po stránce občanské a zároveň nezamezoval prostor pro „bytí Moravcem“ (budoucím Hlučíňanem) v rovině socio-kulturní (etnické a religiózní). Československá administrativa poplatná myšlence budování československého národa nechápe „bytí Moravcem“ jako něco odlišného od češství, čemuž zase většinou nerozumějí obyvatelé Hlučínska. Dochází tak $\mathrm{k}$ institucionálnímu nátlaku jak v meziválečném, tak i v poválečném období (po 2. světové válce) (Plaček 2000). Identifikaci s češstvím „napomáhala“ hrozba konfiskace majetku při opačné volbě. Prostor pro menšinové či subkulturní „hlučínstvi““ ve veřejné sféře byl uzavřen. V národně socialistickém Německu byla jediná volba - „bytí Němcem“, mluva v moravském dialektu byla zakázána a přísně sledována, což působilo potíže lidem z nejstarší pruské generace bez vzdělání, protože její př́slušníci (a zejména př́slušnice) ovládali pouze moravštinu.

\section{Socialistická generace}

V poválečném obnoveném Československu se poměry pro žijící hlučínské generace opět dramaticky změnily. Pruská generace zažívala již druhý návrat do „staronové vlasti“ a snažila se adaptovat na nové podmínky. Starší segment meziválečné generace byl zaměstnán spojováním odloučených rodin či zakládáním nových, nebot' přes válku na to nebyl čas a mnohdy peníze. Lidé pracující v armádě a administrativě Německa se vraceli domů až se zpožděním (např́klad až na podzim roku 1946), které bylo způsobeno úředními tahanicemi kolem jejich občanství.

Byla řešena otázka „viny“ Hlučínanů za jejich př́ślušnost k Německu, kde sehrál roli dekret 33/1945 Sb. ${ }^{8}$ Hlučíňané byli de facto považováni za československé občany, nebot' by nebylo logické je uznat za Němce, když migranti z Ratibořska a okolí získávali status národních hostů. Nezískávali ale občanství de iure automaticky, museli o ně žádat a každý individuální př́pad byl posuzován podle zmíněného dekretu. Ztráta občanství znamenala konfiskaci majetku a nutnost odsunu do Německa. Touha státu po navráceném území opět vede k ponechání obyvatel Hlučínska v jejich domovech. Přesto dochází k výběru osob pro odsun do Německa. Plaček (2000) konstatuje, že část odsunutých lidí označených jako Němci ${ }^{9}$ byla podle jejich mateřské řeči prokazatelně slovanského původu. Avšak původ a mateřský jazyk prý př́i výběru $\mathrm{k}$ odsunu nehrál roli. Mezi závažné důvody patřilo členství v některých nacistických organizacích (zejména ve vy̌šsích funkcích). Naopak smíšená manželství neměla být odsunuta, zde sehrál etnický princip svoji roli.

Přestože historicky známý odsun Němců z Československa ${ }^{10}$ zasáhl obyvatele Hlučínska kvantitativně vzato pouze částečně, vzpomínky na osudy odsunutých či spěšně emigrujících

8 Ústavní dekret 33/1945 Sb. presidenta republiky ze dne 2. srpna 1945 o úpravě československého státního občanství osob národnosti německé a mad’arské je jedním z tzv. Benešových dekretů.

9 Na základě dostupných dat opustilo Hlučínsko v rámci odsunu a odchodu do Německa $8 \%$ populace, což je nesrovnatelně méně než ze Sudet, které se nacházely v odlišné situaci.

10 Odsun Němců z území České republiky byl právně umožněn dekretem 33/1945 Sb. prezidenta republiky, kterým byli českoslovenští Němci (s výjimkou antifašistů) zbaveni státního občanství. 
rodinných př́slušníků zůstaly. Zážitky související s odsunem mohly být přímé a nepř́mé povahy, zajisté však měly pro současníky značnou generační relevanci. V případech př́mého zážitku odchází např́íklad bratr jedné z konverzačních partnerek z meziválečné generace do Německa poté, co je mu v roce 1946 jako Němci vyvlastněn obchůdek. Jiná rodina má dodnes uložený kufŕík na věci do $20 \mathrm{~kg}$ (jedna z norem povolené hmotnosti), se kterým $\mathrm{v}$ rámci organizované fáze odsunu odešla prríbuzná (prateta) a jenž byl této rodině po několika desetiletích darován na památku. Mezi nepř́má a dodnes živá svědectví může patřit vyprávění o prastrýci, který jako šestnáctiletý hoch prchal před frontou (tedy již na jaře roku 1945) z Polska, se zastávkou na rodném Hlučínsku, do Německa.

Mladší kohorty meziválečné generace, které začaly základní školní docházku za Třetí říše, čelily potížím s adaptací na českou školu. Reflexe pamětníků se v otázce př́istupu českých učitelů (pocházejících nejčastěji z jižní Moravy nebo z blízké „císařské“" strany“"11) rozcházejí. Jeden obraz představuje vesměs plynulý proces navykání na češtinu s občasnými úsměvnými nedorozuměními. Kontrastní obraz hovoří o adaptaci přerývané neskrývanými projevy nepochopení vůči jednání a situaci obyvatel Hlučínska.

Ja jsem šel po valce do třidy, ja jsem neuměl ani slovo česky. (1) Ja jsem neuměl ani slovo česky. A, eh, eště po valce nam (1) pusy zavirali, až nemluvime německy. No moja mateřska řeč byla němčina. (...) Učitelé jak ti jeli, jak na Manfred, moja sestra Marichen, bratr Paul, Kurt, Manfred, Helmut. Všichni mame německe mena, oni to nemohli přehryzt že že ty mena - nebo Lotte, Charlotte, Liselotte, Adolf, eh, Willi, Willibald no prostě byly německe mena - byly německe, dneska se davaju jine mena. Kdybysme přišli pod nějakych Činanuv nebo co, tak řeknu, proč jste se takove jmena (dávali), vždyt' to je volovina, ne už do teho.

(M. B., muž, 68 let, narativní ohnisko: poválečná léta)

Německá jména mnohým neustále připomínala pro mnohé těžce stravitelnou minulost, konverzační partner ji však vnímá jako přirozený důsledek svého narození a socializace během přináležení k Německu. Jak pod vlivem stigmatizace všeho německého, tak i z důvodů dobrovolného návratu $\mathrm{k}$ původní podobě jména se Hlučínané nechávali přejmenovat, nebo si nově či zpětně počeštovat jména. Někdy se stávalo, že si jeden z rodinných prríslušníků pozměnil křestní jméno a př́ijmení ponechal v německé transkripci, avšak jiný si nechal počeštit jméno celé (např. Schaffartzik a Šafarčik).

Přes proces počeštování jmen a opětovné zavedení českého školství měla starší a nejstarší generace kulturní identifikace i jazykový úzus pevně internalizovaný. Vzhledem k odlišným biografickým drahám (oproti následujícím generacím) proces počeštění a rozvití identifikací s češstvím nedoznal takové hloubky jako u socialistické generace. Přitom je

V letech 1945-1946 muselo Československo opustit (podle různících se údajů) 2,5 milionu až více než 3 miliony lidí německé národnosti. Na území ČSR zůstalo kolem 250-300 tisíc Němců s omezenými občanskými právy, kterým se oficiálně podařilo prokázat, že si nezadali s nacistickým režimem.

11 Císařská čili „Čisarska“ (strana) je oblast na pravém břehu řeky Opavy, která podle kolektivní paměti patřila rakouskému císaři. V mentální mapě místních obyvatel tak býval vyjádřen rozdíl mezi rakouskou (českou) částí a pruskou (německou) částí Slezska („Čisarska-Prajska“). 
důležité si uvědomit prostý fakt, že rozdíly v datech narození jedinců z nejmladšího segmentu mezi/válečné generace a jedinců z nejstaršího segmentu socialistické generace činily pouze několik let. Podstatné fáze primární a sekundární socializace proběhly ve značně odlišných podmínkách, jež, jak se domnívám, měly podstatný vliv na formování generačních identit.

Formativní vliv významných druhých z rámce primárních skupin (rodina) se dostává do rozporu s působení sekundárních skupin (škola). Vlivem působení české školy po 2. světové válce byl ve většině hlučínských rodin přenos tradičního bilingvismu narušen. Němčina ve spojitosti s protiněmeckým diskurzem je symbolicky vymíst'ována z každodennosti. V jejím ne/zachovávání tkví pomyslná hraniční zóna mezi mezi/válečnou a diverzifikovanou socialistickou generací.

Socialistická generace pod vlivem negativního společenského obrazu reprezentace čehokoliv německého vnímala němčinu jako stigma a zároveň jako cizí jazyk. Muž narozený v jedné z hlučínských obcí v blízkosti Opavy rok po válce (1946) následovně vyhodnocuje svůj vztah ke své tetě v rámci biograficko-narativně vedeného dotazování.

Teta Gusta, ta byla jako vždycky Prajzula, taka odměřena, a mluvila, když 'sme přišli na návštěvu, enem německy.

(F. R., muž, 60 let, narativní ohnisko: druhá polovina 50. let 20. stol.)

Konverzační partner cítil ke své tetě jisté odcizení skrze fakt, že s ní měl v podstatě znemožněnou komunikaci, hovorů se mohl účastnit pouze jeho otec (bratranec paní Gusty), který absolvoval německé školy (základní vzdělání a vyučení v oboru), základní vojenskou službu vykonával v polovině třicátých let v československé armádě a ve válečných letech jako příslušník německé armády sloužil na východní frontě. Sama teta přitom ovládala i další řečový kód v podobě moravštiny. Odcizení je naznačeno vícevýznamovým pojmem, jehož konotace se mění s kontextem. „Prajzula“ může vystupovat jako pozitivní výraz pro ztotožnění se s rodným krajem, v ukázce funguje jako označení identifikace s němectvím.

Rozpad jazykové loajality vưči německému jazyku nezasáhl všechny hlučínské rodiny a mezi zasaženými neprobíhal rovnoměrně. Zejména v okolí Kravař ve Slezsku a v některých přilehlých obcích zůstal vyšší počet osob, které se sebe-identifikovaly jako Němci, a také se zde ve větší míře zachovaly intenzivní vazby na příbuzné, kteří zůstali v Německu anebo tam odešli z vlastní volby či byli deportováni navzdory své vůli. Přesto lze na úrovni generalizace pro mikroregion jako celek konstatovat, že mezigenerační přenos etnokulturního dualismu byl přerušen, kulturní reprezentace němectví utlumeny.

Další významnou institucí pro utváření sociálních identit obyvatel Hlučínska bylo náboženství. Jelikož sakrální se odvíjí mnohdy v jiných směrech a dimenzích než profánní, z hlediska přináležení k organizaci katolické církve nikdy nedošlo k přerušení vazeb na katolickou Moravu. ${ }^{12}$ Podobně jako Bismarckův vyhlášený „kulturní boj“ vedený od 70. let 19. století z pozic protestantismu nezničil katolickou víru ani ideologický boj komunistů po 2. světové válce vycházející z pozic historického materialismu. Fáze tuhého omezování náboženského života v letech 1948-1954, která vedla k silně vypjatým vztahům, byla vystří-

12 Děkanáty Hlubčice, Hlučín a Ketř patřily k olomoucké diecézi (od roku 1777 bylo biskupství povýšeno na arcibiskupství olomoucké) (Stoklasa 2006). 
dána systematickým tlakem režimu a neméně pevnou ignorací režimních snah ze strany věřících. Lidé z řad státních zaměstnanců sice byli nuceni postupovat opatrně a sociální praktiky spjaté s vírou privatizovat či navštěvovat kostel mimo své bydliště, aby se „o tom nevědělo“. Jednou ze změn v religiozitě (či náboženské identitě), $\mathrm{k}$ níž došlo v socialistické generaci oproti generacím předchozím, byla jistá formalizace v př́stupu k náboženství. Řada křtěných a biřmovaných katolíků přestala navštěvovat kostely či se z nich stali katolíci „dvakrát za rok“ (návštěva vánoční a velikonoční mše svaté). Změna $\mathrm{v}$ jednání počala vyprazdňovat obsah samotné sociální instituce. ${ }^{13}$

Pokud bychom argumentovali, že generační identity předchozích dvou generací byly posíleny silnými traumatickými zkušenostmi (světové války, hospodárská krize, ideologie, symbolické vymístění) vznikajícími na pozadí velikých dějinných událostí, u socialistické generace do roku 1989 lze spíše hovořit o jejím oslabování sérií méně zlomových dějů. Důležité milníky mezi lety 1948-1989, jako padesátá léta, rok 1968, normalizace v letech sedmdesátých, mají dopad na celou společnost tehdejšího Československa a nikoliv specifický dopad na Hlučínsko (snad s výjimkou padesátých let a roku 1960, kdy byl oficiálně zrušen okres Hlučín rozdělením mezi okresy Ostrava-město a Opava).

Významným obratem z hlediska diskurzu o hlučínském problému je až fáze po roce 1989. Do této doby nejsou patrné projevy věkových kohort ve velmi přibližném rozmezí let 1942-1964, které až v období porevoluční transformace české společnosti reprezentují svoji generační identitu hledáním hlučínské svébytnosti a specifičnosti. Ta se již na počátku devadesátých let projevila např́iklad vznikem Sdružení obcí Hlučínska, jehož podstatným důvodem bylo hájit zájmy obyvatel ${ }^{14}$ žijících v sídlech tohoto historického mikroregionu a tento rovněž propagovat např́klad z hlediska cestovního ruchu. Dále došlo k oživení v oblasti publicistiky (monografie o jednotlivých obcích a jedna o regionu) i v menší míre v odborné literatuře, kde se začíná psát o tématech dřive tabuizovaných či nepreferovaných (pohled z hlučínských pozic, např́klad na válku). Rámce tabu překročila i sociální praxe umístování pomníků padlých vojáků z 1. a 2. světové války v jednotlivých obcích (myšleno vojáků z řad německé armády, mnohdy se jmény $\mathrm{v}$ jejich germanizované podobě). ${ }^{15}$

\section{Generace roku 1989}

Sociální změna prostupuje dále uzemním společenstvím na Hlučínsku a nejbadatelněji se tento proces projevuje u mladších věkových kohort. Záměrně není použito pojmu generace, nebot': 1) zdá se, že je př́liš brzy hovořit o zformování sdílené generační identity a 2) je to

13 Přesto kvantitativně vzato je mikroregion Hlučínska územím s vysokou religiozitou (v některých obcích více než 85 \% věřících oproti necelým $30 \%$ celorepublikového průměru).

14 Sdružení obcí Hlučínska mělo vliv na formování restitučních zákonů. Text jejich prohlášení je např́klad citován poslancem J. Piskořem při projednávání zákona o půdě 30. 1. 1992. Poslanec Zbyšek Stodůlka obdobně na př́kladu Hlučínska připomíná nutnost odstranění majetkových křivd z poválečného období až let šedesátých (15.4. 1992).

15 Což je logický důsledek tehdejší doby a znění jmen v německých soupisech padlých. Na druhou stranu se vyskytly i nesouhlasné hlasy, podle kterých by se namísto „Georga“ lépe vyjímal na pomníku „Jiřri“, jenž by si to „také určitě takto přál““ (Martiník 1997). 
dáno tím, že $\mathrm{v}$ takto definované skupině se projevuje značná diverzita reprezentací a identifikací. Společným prvkem je patrně pouze skutečnost společného regionálního původu, cesty, jakými je tento fakt vnímán (a zdali je vůbec reflektován), se značně liší. Dalším významným sdíleným prvkem, který patrně nikoho nepřekvapí (a přesto je nezbytné na něj poukázat), je vliv rodiny a rodinných vazeb ${ }^{16}$ na formování obsahu sociální identity ve vztahu k Hlučínsku. Svoji roli rodina sehrává jak na úrovni hodnotových orientací (identifikace), tak rovněž $\mathrm{v}$ rovině sociálních praktik (instituce a reprezentace).

Pracovně nazvaná „Generace roku 1989“ sestává z těch kohort lidí, jejichž životy byly ovlivněny velkou strukturální změnou, která vzniká pod vlivem událostí z konce roku 1989 a následné celkové společenské transformace. $Z$ hlediska temporálního rozpětí tato změna zasahuje aktéry (v pořadí od dříve narozených $\mathrm{k}$ mladším) v životní fázi rané dospělosti až $\mathrm{v}$ útlém dětství.

Ve srovnání s předchozí socialistickou generací (z notné části generací rodičů) lze načrtnout některé menší změny, v celkovém pohledu pak můžeme konstatovat plynulou kontinuitu ve fungování i rozpadu identifikačních vazeb a institucí.

Ve sféře regionální identity dochází k přirozenému přenosu lokálního patriotismu, vztahu ke kraji, který je prakticky oproštěn od nacionálně pojatého rámce. Vztah k původu „z Hlučínska“ nabývá různé povahy: od geograficky chápané vazby (,mám to tady ráda, protože jsem se tu narodila a vyrostla“) až ke vzácnějšímu pojetí kulturně specifického regionu s pohnutou historií. Druhý typ regionální identity je charakteristický zachováváním hodnotových orientací a identifikací souvisejících s kulturní tradicí (alespoň formální zachovávání sociálních praktik vázaných na katolickou víru, respektování nedělního pracovního klidu, časté a pravidelné společné rodinné slavnosti, pro užší skupinu Hlučínanů mladší a stř̌ední generace zachováváním folklórních tradic - písní, tanců a pohádek). ${ }^{17}$

Z hlediska etnické identity (ve smyslu př́slušnosti k národu) a ztíženě od ní odlišitelné politické identity (ve smyslu př́slušnosti ke státu) dochází k prolínání jednotlivých významových rovin a vrstev identifikací, pozitivním jevem pak je ubývání konfliktních rámců. Zatímco Lozoviuk (2005) konstatuje u obyvatel Kladska (tzv. Prajzi v bývalém Kladském hrabství na severu Čech) a Hlučínska existenci etnické indiference, na základě provedeného výzkumu se tato hypotéza ukazuje jako platná v př́ípadě starší a střední generace, u mladší generace pozorujeme proces „zdomácněni“ přinejmenším v institucionálním rámci České republiky. Vztah k národu ve smyslu češství je komplikovaný a hưře interpretovatelný vlivem zemsky pojatého hlučínství či šiřeji chápaného slezanství. Průvodním znakem této reprezentace je aktivní vymezování se vůči Čechům v Čechách, a to zejména v Praze, jež je známé i z jiných regionů ČR.

16 V rovině poznaného vlivu rodinných vazeb se zúročuje úsilí provádět biograficko-narativní rozhovory v rámci jednotlivých rodin mezi členy jednotlivých rodinných generací. Inspirací před vstupem do terénu byl koncept př́padové historie rodiny (case family history) (Bertaux and Delcroix 2000).

17 Samotná schopnost reflektovat tyto vztahy je dána celkovou intelektuální úrovní jedince (kulturní kapitál převážně reprodukovaný orientační rodinou). 
Vícevrstevnost nekonfliktního pojetí sebe-identity u mladší generace („roku 1989“) je badatelná na „učebnicovém“, nicméně nikoliv smyšleném výroku hlučínské informantky během rozhovoru: „Jsem Češka a Prajzula a Kravaračka“ (Š. G., žena, 26 let, narativní ohnisko: současnost). Od politické (protože není zcela jisté, že etnické) identity vyjadřující vztah př́slušnosti ke státu, přes regionální identitu, až k lokální vazbě k rodné obci se Šárka cítí doma ve všech zmíněných komunitách (od té pomyslné až k oné postavené na bázi vztahů „tváŕí v tváŕr").

Přesto je zde něco, co od počátku devadesátých let „vzrušuje“ publicisty a „rozčiluje“ méně obeznámené spoluobčany - Šárka a s ní (podle odhadu interního názorového vůdce z Hlučínska Ericha Šefč́íka $)^{18}$ asi třetina obyvatel Hlučínska přes svou prŕslušnost k Česku podstoupila úspěšné kroky ke získání německého občanství. Nedochází však k masové trvalé emigraci z republiky či dokonce $\mathrm{k}$ depopulaci kraje. Narativa i pozorované chování obyvatel prokazují, že nabývání německého občanství mělo a má zejména praktický význam pro možnost volnějšího cestování a získání pracovních př́ležitostí v zemích Evropské unie (EU) i mimo ně. I po vstupu do EU jsou mnohé pracovní trhy členských zemí pro „nováčky“ uzavřeny. Ne tak pro obyvatele Hlučínska, kteř́ byli schopni na základě dokumentace podat důkaz o „němectví“ svých předků (např. služba předka u německé armády). Lidé nepracují pouze v Německu, mezi cílové státy pracovní migrace patř́ rovněž Holandsko, Irsko, Velká Británie či USA. Německý pas tedy slouží spiše jako kouzelný klíč otevírající brány hraničních přechodů a pracovních trhů než jako činitel vzniku nové „páté kolony“. Pohraniční umístění regionu značící vyšší míru ohrožení nezaměstnaností či sníženou možností sehnat práci odpovídající profesní kvalifikaci je významným faktorem, jenž podporuje tempo pracovní migrace. Ruku v ruce s ním působí obava ze stigmatizace nezaměstnaností.

Otázka etnické identifikace či spíše ztotožnění se s pomyslnými komunitami v podobě národů je v mladší generaci řešena ve prospěch češství, byt' v rodinách s intenzivními vazbami na Německo se zachovává deklarovaná př́slušnost k německé národnosti. Vedle skupiny mladých lidí, kteří konstruují svoji etnickou identitu přímo po rodičích jako německou („Otec je Němec, jezdí do Německa, já jsem taky Němec!“") ${ }^{19}$, existují na opačném pólu mladí lidé odmítající jakoukoliv spojitost s minulostí spjatou s Německem, skrze niž bývá konstruováno „prajzáctvi“. Vymezují se od něj hodnotově anebo prostorově (např́klad tvrzením o tom, že konkrétní část obce není a nebyla německá a její obyvatelé „nejsou Němci“). Ve vztahu mezi prarodiči a vnuky/vnučkami dochází při rodinných setkáních mnohdy k polemice, nebot’ dědeček z mezi/válečné generace se „cítí jako Němec“, jeho syn s ním již tuto identifikaci nesdílí a vnučka ji odmítá („Žiju tady, tady chodím do školy, jsem Češka“; V. H., žena, 23 let, narativní ohnisko: současnost).

18 PhDr. Erich Šefč́́k sehrává aktivní roli v prezentaci regionu, výkladu chování jeho obyvatel v médiích (údaj o třetině Hlučíňanů s německými pasy uvedl v německém znění rozhlasového vysílání Rádia Praha, Český rozhlas 7 ve dnech 3. 2. a 7. 2. 2004) a jako historik v rozvoji poznání o regionu (publikační a ediční činnost).

19 Otec konverzačního partnera Honzy (na Hlučínsku vyslovováno často v podobě Hanys) dlouhodobě žije a pracuje v Německu a má německé občanství. 
Rovněž aspekty náboženské identity prodělávají, skrze rupturu v socialistické generaci, postupnou změnu. V rodinách, kde nedošlo k přerušení tradice předávání religiozity, se v nové porevoluční době, která umožňuje svobodu vyznání bez společenské stigmatizace, podařilo dokonce reprezentace víry posílit (pravidelná návštěva kostela, obce nechávají světit své obecní prapory, děti a mládež jsou vedeny k náboženské praxi) či přinejmenším zachovat. Přesto je pro Hlučínsko typické rozdělení genderových prostorů komunikace (ženy - kostel, muži - hospoda) v rovině ženského rodu zachováváno pouze nejstarší generací. Věřící vnučky hlučínských babiček svoji víru privatizují v podobě domácí modlitby a setkávání s mladými lidmi prostřednictvím křest’anských organizací pro mládež. Z pohledu každodenního běhu života (dojížd'ka za prací, péče o domácnost) je na kostel čas pouze v neděli i u střední generace. Druhým procesem započatým za socialistické generace (vliv výchovy a stigmatizace věřících) je formalizace víry a postupný rozpad religiozity u notné části generace roku 1989. Vliv na narušení přenosu religiozity má změna v hodnotových orientacích mladých lidí se slabým důrazem rodičů na náboženskou výchovu (po křtu veskrze upuštění od jakýchkoliv náboženských praktik a aktivit).

Nejtrvalejším pomníkem „hlučínské otázce“ či „,př́běhu obyvatel Hlučínska“ jsou dodnes předávané stereotypní představy. Setkávají se s nimi dodnes i mladí Hlučíňané generace roku 1989. Na druhou stranu díky nim ,region existuje“ i po více než čtyřiceti letech oficiálního zrušení okresu nesoucího jeho jméno. Nejčastěji jsou akcentovány odlišné hodnotové orientace obyvatel Hlučínska, které vyplývají ze sociálních interakcí s lidmi z Opavska a Ostravska. ${ }^{20}$ Přesto však vyprávění o osudech zemičky ${ }^{21}$ nazvané Hlučínsko mizí postupně z myslí lidí tak, jak přicházejí nové generace a stírají se dřívější rozdíly mezi populacemi. A proto, dokud to jde, není bez badatelského významu se pohraničním územním společenstvím věnovat.

\section{Literatura}

Adorno, T. W. a kol. 1950. The Authoritarian Personality. New York: Harper and Row.

Alheit, P. 2003. „Biografie a mentality: Nový př́stup mezinárodního srovnávacího výzkumu.“ In F. Zich (ed.) Regionální identita obyvatel v pohraničí. Praha: Sociologický ústav AV ČR, s. 111-129.

Berger, P. L.; Luckmann, T. 1999 [1966]. Sociální konstrukce reality. Pojednání o sociologii vědění. Brno: CDK.

Baudrillard, J. 1988. „Simulacra and Simulations.“ In J. Baudrillard. Selected Writings. ed. by M. Poster. Stanford: Stanford University Press, s. 166-184.

Bertaux, D.; Delcroix, C. 2000. „Case Histories of Families and Social Processes.“ In P. Chamberlayne, J. Bornat, T. Wengraf (eds.) The Turn To Biographical Methods. In: Social Science. Comparative Issues and Examples. London, New York: Routledge, s. 71-89.

20 Např́íklad šetrnost se dá interpretovat jako ctnost či jako skrblictví (v negativním vymezení by si podle některých obyvatel z okolí Hlučínska „nechal Prajzák koleno vrtat"). Šetrnost vyvěrá z dřívější rozšířené chudoby, jež byla mnohdy na hranici bídy, a patrně z vlivu weberovsky pojaté protestantské etiky (Prusko) vytěžit ze směny maximum zisku.

21 Podle malebného německého názvu Hlučínska „Hultschiner Ländchen“. 
Bourdieu, P. 1998. Teorie jednání. Praha: Karolinum.

Corsten, M. 1999. „The Time of Generations.“ Time \& Society, Vol. 8 (2): 249-272.

Edelstein, W. 2005. „The Rise of Right-Wing Extremist Youth Culture in Postunification Germany." L. Nucci (ed.) Conflict, Contradiction, and Contrarian Elements. In: Moral Development and Education. New Jersey: Lawrence Erlbaum Associates, s. 157-172.

Edmunds, J.; Turner, B. S. 2005. „Global Generations: Social Change in the Twentieth Century." The British Journal of Sociology, vol. 54 (4): 559-577.

Eyrman, R. 2004. „The Past in the Present: Culture and Transmission of Memory.“ Acta Sociologica, 47 (2): 159-169.

Gawrecki, D. a kol. 2003. Dějiny Českého Slezska. Opava: Slezská univerzita.

Giddens, A. 1991. Modernity and Self-Identity: Self and Society in the Late Modern Age. Stanford, CA: Stanford University Press.

Hořká, L. 1975. Trnité cesty. Ostrava: Profil.

Howe, N.; Strauss, W. 1992. Generations: The History of America's Future, 1584 to 2069. New York: Harper Perennial.

Howe, N.; Strauss, W. 1997. The Fourth Turning: An American Prophecy. New York: Broadway Books.

Keller, J. 2004. Dějiny klasické sociologie. Praha: SLON.

Konopásek, Z. 1998. Estetika sociálního státu. O krizi reprezentace (nejen) v sociálním zabezpečení. Praha: G plus G.

Lozoviuk, P. 2005. „Etnická indiference a její reflexe v etnologii.“ In T. Hirt, M. Jakoubek (eds.). Soudobé spory o multikulturalismus a politiku identit: Antropologické perspektivy. Plzeň: Nakladatelství Aleš Čeněk, s. 162-197.

Lüscher, K. 1993. „Generationenbeziehung - Neue Zugänge zu einem alten Thema.“ In K. Lüscher a F. Schultheis (eds.). Generationenbeziehungen in „postmodernen “ Gesellschaften. Konstanz: Konstanz Universitätsverlag, s. 17-47.

Mannheim, K. 1952 [1928]. „The Problem of Generations.“ In Essays on the Sociology of Knowledge. London: Routledge \& Kegan Paul, s. 276-320.

Mars, L. 1999. „Discontinuity, Tradition, and Innovation: Anthropological Reflections on Jewish Identity in Contemporary Hungary." Social Compass, Vol. 46 (1): 21-33.

Martiník, L. 1997. Žil jsem na Hlučinsku i na straně císařské. Opava: L. Martiník, vl. n.

Mills, Ch. W. 2002 [1959]. Sociologická imaginace. Praha: SLON.

Mišíková, J.; Kövérová, Š. 1992. „Nie je generácia ako generácia.“ Sociológia 24 (6): 545-553.

Pavlíček, J. 2003. Opavské Slezsko v boji proti nacistické okupaci. Opava: Matice slezská.

Pilcher, J. 1994. „Mannheim’s Sociology of Generations: An Undervalued Legacy.“ British Journal of Sociology, Sep. 94, Vol. 45 (3): 481-494.

Scholz, J. J. (ed.) 1991. August Scholtis: Briefe, Teil I. Berlin: J. Scholz.

Siegel, T. 1985. „Wage Policy in Nazi Germany.“ Politics \& Society, Vol. 14 (1): 1-51.

Stoklasa, H. 2006. Kráčeli cestou dlouhou. Kravaře: Město Kravaře.

Svátek, F. 1998. „Zkušenost tří generací s totalitarismy.“ In M. Pułaski, J. Valenta (eds.). Zkušenost tř́ generaci Poláků, Čechů a Slováků. Vratislav: Uniwersytet Wrocławski, s. $155-178$. 
Veith, W. 2006a. Intergenerationelle Gerechtigkeit. Ein Beitrag zur sozial-ethischen Theoriebilgung. Stuttgart: Kohlhammer.

Veith, W. 2006b. „Intergenerationelle Gerechtigkeit.“ Soziales Seminar: Informationen, No. 2, Nov 06: 1-4.

Vincent, J. A. 2005. „Understanding Generations: Political Economy and Culture in an Ageing Society.“ The British Journal of Sociology, Vol. 56 (4): 579-599.

\section{Autor}

Marcel Mečiar je externím doktorandem oboru sociologie na Katedře sociologie FSS MU, kde píše disertaci na téma Mezigenerační proměny sociálních identit obyvatel Hlučínska. Jako pedagog a badatel působí na Katedře společenských věd Pedagogické fakulty Ostravské univerzity, kde se věnuje výuce úvodu do sociologie, prostorové sociologie a sociologie rodiny a výchovy a badatelsky se zaměřuje na formování sociálních identit (učitelé občanské výchovy, imigranti, fotbaloví chuligáni atd.) a problematiku multikulturního soužití. V důsledku životních náhod žije $\mathrm{v}$ okrajové části historického mikroregionu Hlučínska, kam jej zaválo založení vlastní (prokreační) rodiny. Kontakt: marcel.meciar@osu.cz 